\title{
Man's Journey Through Space, Time and Logos. Reflections of Narcissus' Myth in Solarium by Jordan Zandi
}

\author{
Claudia Pisoschi, PhD \\ University of Craiova Romania
}

Doi: 10.19044/esj.2018.c3p12～URL:http://dx.doi.org/10.19044/esj.2018.c3p12

\begin{abstract}
The paper is meant to be a text analysis of the poem Solarium by Jordan Zandi in point of the significance of space, time and logos dimensions. The pragma-stylistic perspective adopted will allow us to identify how Narcissus' myth is reflected in Zandi's poem by comparing it to the complex reference text which is Ovid's Metamorphoses (Book III). Like Narcissus, the poetic voice in Solarium makes a journey through time and space. Primordial elements (fire, air, water, earth) with their infinite concrete manifestations are symbols of the continuous change chain that life and death are part of. Man himself becomes not only the (gradually aware) subject, but also the symbolic expression, of a total metamorphosis of matter into conscience through logos.
\end{abstract}

Keywords: Metamorphosis, space, time, logos, matter vs. conscience

\section{Introduction}

Human life is by definition a journey through space and time, and Narcissus' myth is the expression of the continuous quest for (self)-knowledge at any price, sacrificing the perfect appearance valued within a limited space for the sake of discovering one's essence.

Starting from the idea, shared by the materialist philosophers of the antiquity, that matter and conscience are independent, the latter reflecting the former, Ovid added new significances to the three fundamental forms of manifestation of matter: space, time and change. Ovid is known to have been mostly interested in and even adopted, Heraclitus' philosophical system, reinterpreting or adding to its significations, some turned into myths. Dana Marinescu (2003: p.1, para 3) talks about Ovid having the 'obsession of Heraclitus' flux, a succession, but also something beyond form, a change at both the level of the living world and of the human psyche' (our translation). It is exactly what the myth of Narcissus reinterpreted by Ovid expresses. 
At the same time, the poetic voice in Jordan Zandi's poem Solarium is a contemporary Narcissus interpreting the space and time coordinates of his everyday universe as reflections of his own change.

Though space and time should be seen as a continuum, for the sake of our analysis we shall try to discuss them separately, in point of their common and different values in the two poems.The opposition body-mind, better said the monist view which 'puts' mind inside matter, is at the basis of our interpretation.

\section{The human journey through space: from appearance to essence, from outer to inner space. Space and God/gods}

In our view, space, like time, should be seen as including physical space, belonging to the external world and perceptible through senses and psychological space, i.e. physical (real) or imagined spaces, interpreted/created by people according to their rationality and affectivity. Both types of spaces are dominated by forces and barriers and together, they constitute the realm of the living and that of the dead; the latter is a symbolic, mythical space, a reflection of the former which is knowable. According to some ancient beliefs, both realms are governed by supernatural forces, by gods, implacable in their perpetual people's temptation to excess (hybris), which is severely punished afterwards.

Space is perceived in the form of concrete elements which exist governed by celestial time (i.e. physical time), controlled by God(s) and in (an attempted) harmony with nature's time; these elements make up the physical space of nature itself (including humans). Therefore, physical space is dominated by the four primordial elements, fire - air - water - earth, symbols of both life and death. Fire, air, water and earth take various concrete forms, make up sub-worlds valued as part of the cosmos and of the human universe, as a result of their reflection in the mind and soul of the human beings.

Earth is viewed by Heraclitus as the basis of the ascendant chain of metamorphoses, and also the last in the downward cycle of changes undergone by the principle fire. It is associated to the beginning, to roots, to materiality. Plants, animals, humans, all objects depend on and are realizations of, the principle earth. For a human being, earth means anything connecting him to the physical dimension of existence: family, family house, the yard, the garden, the fruits of the earth, the familiar ground.

The title of Jordan Zandi's poem, Solarium < Lat. 'terrace', 'porch' is in itself a metaphor of an intermediary space which makes the transition from the outer space, this space of earthly life, to the space of afterlife. The porch is a space of tranquil reflection meant to facilitate the beginning of the inner quest for God, for the essence. The solarium is also the intermediary space 
between the confining walls of the house (and mind) and the implicit garden representing the universe to be discovered.

In Solarium physical spaces are organised as two opposite areas: the area of the house having the features [+protective], [+familiar], [+nostalgic], but [+limiting], and the area outside the house - the field, the city - with the features [+menacing], [+tough] but also [+challenging], [+attractive], separated by the river, seen as a symbol of the barriers which limit knowledge, spiritual life.

The poet makes a journey from the private space, the inner space of the family and family house to the external space, crossing the barrier which separates the known (boring, limiting) from the unknown (stimulating. liberating). The barrier is the river that he must cross, in a way another form of the Styx; across the river the train sound is reflected in the poet's mind as the catalyst of his quest: I've heard the train horn bawl out again from across the river, first sound/ I remember,[...] (Zandi, n.d., https://www.jordanzandi.com/poems).

In Ovid's Metamorphoses it is the nymph Echo who stands for the reflection of sounds; she is the transition element from the known materiality to the unknown spiritual essence. Once she is possessed by 'the inner fire', she is no longer a recipient, she actually becomes the active principle that turns sounds into logos causing Narcissus to fulfil his destiny and surpass his condition: Echo only repeats the last of what is spoken and returns the words she hears. [...]but she is ready for what it will allow her to do, to wait for sounds, to which she can return words (Ovid, M, B III: 359-401, para 1).

Ultimately, the most concrete physical space is one's body and the two poems reveal the intricate relationship matter-spirit. In Solarium the poet becomes reflection and enters the bodies of God's Creation forms, from the mouse to the quinces. Hunger for food becomes 'an inner fire' manifested through matter. Thus, the poet enters the animals' instinctual spaces and the realm of plants, tasting their prey/them, 'tasting' their/his victory and reflecting them/on them.

To Zandi-the child, survival by killing the prey, as a condition of materiality, appears surprising, repugnant but catching one's attention, a moment to be shared with the family. It is an image of victory: 'Quick - to the window, Mother/ come see - the coyote/ he's dragging a haunch by the bone'. The coyotes coming loping over across the frost-flocked rows of the field are the symbol of flesh, of instincts at work and the poet is 'sinking his teeth' into reality to get to its sap, like the coyote dragging its prey, laying it down, lying down and sinking its teeth into it.

The poet 'enters' the body of the tireless mouse turned into his alterego and, possessed by hunger as a form of change, chews paper but also wires, which are the symbol of light, of fire, because the man-mouse wants to get to 
the light. The mouse's victory is also his, but the image of the deserted room like a banquet hall signifies hunger for permanence opposed to the decaying matter devoured by time.

Last but not least, there is the symbol of quinces, the act of chewing the quince pulp turned him into a spiritualized fruit, i.e. giving beauty and joy to the others: Beautiful ones - I see you everywhere./ Hiding inside yourselves. Material world is known through experience and turned into logos, but the others' inability to understand the essence makes the poet (as a child) withdraw into a world of his own, mocked at by ordinary people who reduce all to appearance: Remember summer, Jordan?/ Eating quinces, spitting the seeds?/ And how you never ate quinces again/ when they laughed when you called them quinces? Reality which is not known through logos can perish, because it is a product of reflection: And now there are no more quinces?

If Zandi experinces life and spiritual quest outside his human body, Narcissus goes even further, 'sinking his teeth' into his own body, a symbol of perfection and also a part of nature. He is not afraid of destroying appearances that hide or block the search for essence:

While he weeps, he tears at the top of his clothes: then strikes his naked chest with hands of marble. His chest flushes red when they strike it, as apples are often pale in part, part red, or as grapes in their different bunches are stained with purple when they are not yet ripe (Ovid, M, B III: 474-510, para1).

Zandi acknowledges that the mouse's appearance, which is the counter-example of perfect beauty, is matter but also spirit manifesting itself through matter; it can be his alter-ego, whose destruction would mean his destruction: The dream is big, the dream is fancy:/ The dream is big and fancy./ The rodent: cuddly; but a little dirty./I'll keep him as a pet, I'll pet him likel a luck-charm-.

Within the physical space limits, Narcissus and Echo undergo a complete change. He changes into a flower, instead of his body, with white petals surrounding a yellow heart, she changes into a stone. A whole pseudomyth was created around Narcissus' metamorphosis (Kernbach, 1989: 414), and we will later refer to the significance of Echo's change in relation to the opposition matter-conscience.

Physical spaces are all also spiritual spaces, psychological spaces, created as a result of the emotional experiences and informational load associated to them; they emerge according to the poet's activated inner resources.

The myth of Narcissus in Ovid's poem expresses the forced entry (the rape of nymph Liriope whom once the river-god Cephisus clasped in his winding streams, and took by force) (idem, B III: 339-358, para 1) into the inner space of reflection (under the waves). Water is the primordial element 
having the physical property of reflection, further interpreted metaphorically as triggering human spiritual evolution. Narcissus' mother is described as dusky Liriope, the loveliest of nymphs, her dark colour signifying absorption of light, inclination towards the invisible, towards mystery.

Spirituality is present from the beginning of the poem Solarium, the image of the roses can be interpreted as a metonymy for the Garden of Eden because of the wished presence of God; the poet assumes the identity of an ordinary human being who tries to see beyond the beauty of a summer morning, beyond the splendour of the earthly space and experience the vision of God; it is a spiritual space which is a projection of the human mind, a reflection of human spiritual needs:

And daybreak! The sun

sitting up-

\section{Oh God}

I thought I saw God spread out

in the roses again - (Zandi, n.d., op.cit.)

'A deep piety, the reflection of a strong religious belief emerges from the image of God spread onto His Creation, apparently counterbalanced by the inappropriate use of the invocation term God become part of an everyday structure; the succession interjection+Vocative, a lexical bundle, whose functional behaviour as a unit is stressed by the lack of the comma after the interjection, combines its value as an emotive function marker and a phatic marker. The amazement meant to draw the reader's attention connotes desacralization, but, at the beginning of the poem, and equally throughout it, the sacred essence remains transparent beyond the common structures and pragmatic functions'(Pisoschi, 2017: 155).

An animistic philosophy transpires from the structure spread out in the roses; the preposition in expresses the presence of the divine essence not as something external, but as the inner nature of all things. At the same time, the preposition marks the borders of a closed, protected space, that of the rose calice, the material beauty beyond which the human soul longs to find spiritual grace. But spiritual evolution is desired to take place here, on Earth, whose splendid symbol of fruitfulness roses are.

Animism is evident in Ovid's poem: nymphs of the rivers and mountains live among humans, sharing the same spiritualised space: remote fields, hills where shepherds graze their flocks or mountains where youths hunt. The physical space is the background with which humans seem to live in harmony, without excluding killing. There is a clear opposite symbolism of natural elements: open spaces are dominated by sun, by light and instinctual forces are at work there; dark spaces are mysterious and protective, favouring reflection, the active principle of fire operates there at the level of the human 
mind and soul; both Echo and Narcissus enter these isolated, pure and purifying spaces:

Scorned, she [Echo] wanders in the woods and hides her face in shame among the leaves, and from that time on lives in lonely caves. [...] There was an unclouded fountain, with silver-bright water, which neither shepherds nor goats grazing the hills, nor other flocks, touched, that no animal or bird disturbed not even a branch falling from a tree. Grass was around it, fed by the moisture nearby, and a grove of trees that prevented the sun from warming the place (Ovid, M, B III: 359-401, para 4)

Returning to the anthropic world of the poem Solarium, in childhood one would appreciate the presence of a series of elements subsumed to the family house world: the back porch, the rose garden, all the flowers, the quinces make up a world of textures, colours, aromas and tastes. 'They are a closed world that enchants the child, but bores the young man hungry for knowledge and adventure' (Pisoschi, op.cit.: 160). Materiality is associated to death, a spiritual death, experienced by all people who allow themselves to turn into dead things, void of their essence. The poet abruptly questions them, us and himself at the beginning of the poem:

Dead things gumming the sidewalk

Hello, dead things.

Tell me: What good is a life that wears away? (Zandi, n.d., op.cit.)

The space of the city seems to be populated with beings that have lost their human essence, the desire to search their souls, to know what is beyond matter: they become sheer materiality, amorphous substance covering the sidewalks, like a layer of soft tissue. For the poet, such a life is synonymous to death. He was initially also part of this non-spiritual space, but he associates it primarily to the countryside landscape of his childhood and youth and not to the urban space where he is also surrounded by such 'dead things'. He realizes that his journey in space might have been, at least up to a point, a journey towards involution, since he had become one of the dead things. He becomes aware of that and begins his true spiritual quest which makes him reconsider all the spaces he lived in or went through and their significance: 
I was a dead thing once.

On the back porch once-

facing the square

of my mother's rose-

garden, with the northfacing windows

full-opened in June, and other flowers,

the names I've forgotten, all gone

into bloom, [...] (idem)

The names of the flowers are forgotten ([...] and other flowers, / the names I've forgotten, all gone/ into bloom). Beauty turns into ugliness, the protective and cosy space into a scary one, life into death: the arrangement of the lines, their abrupt pauses, create for readers expectations linked to the interpretation of concrete elements: you imagine someone literally lying dead on the porch, the square is automatically associated to a grave with a rose on it, the greenhouse is like a fragile shelter exposed to north winds, hoping for summer sun. It can be a metaphor of our life. Even the verbal expression gone into bloom sounds strange since it makes one think of going into a state of decay, depreciation, oblivion etc, not into a state of full development.

Maybe the poet lived in a house like the one he describes, broke free and now 'casts the stone' of raising our awareness of the spiritual dimension of life. In the end, the house is a deserted space, like an empty shell and all its defining symbols turn into items perceived negatively: the flowered wallpaper looks like a pale image of real flowers, it is an attempt to edulcorate the physical and spiritual space of one's home; the charming table is a collocation sending an ironical message, since it should be the symbol of unity and harmony, but it remains just a space subject to decay and to the silence of a deep, permanent isolation, like the walls of an empty house; noise means life, and once life exits this space, it leaves place to death, associated to silence:

Oh! Look at this charming table:

already set; built for a mouse;

and silent as a banquet hall

after the guests have gone. (idem)

Lack of spirituality makes people turn into dead things, familiar rooms turn into deserted banquet halls, childhood houses turn into empty rooms tolling the echo of the train howl.

Materiality means desire, instinct, the condition of one's surpassing his condition and surviving spiritually. Both Narcissus and Zandi love life beyond its material dimension, but through it. 
The familiar image of the family house, a concrete manifestation of stability and protection, becomes a space of the mind, a border zone, between life and death. The door with the red curtain flapping can be associated, due to its color, to the bood pulsating in one's veins, but it is also similar to the river Styx, threatening and mysterious, because no one ever returns after crossing it. In spite of people's fear of death Heraclitus stated that „'For men who die there await things they do not expect or anticipate' (B27). Some of these remarks tend to suggest an afterlife with rewards and punishment, [...]. In any case, Heraclitus views the soul as the moral and cognitive center of human experience"(Graham, Daniel W., 2015: part 6, para 2).

Ovid seems to share this view and his Narcissus welcomes his own death as the condition of continuing his quest, while Zandi states I will not die here, that is in a despiritualized space, because the one who is going is going, i.e. entering another type of space, never returning to what he knows. It is rebellion and pride in his attitude (What good is a life that wears away?), as it is pride in the delicate form of Narcissus, worn away little by little by the hidden fire. The latter's physical perfection made him separate himself from the others (the faithful band of followers, girls, youths, nymphs) whose desire seemed inferior to him. And, like Narcissus, who even when he had been received into the house of shadows, he gazed into the Stygian waters (Ovid, $M, B$ III: 474-510, para 4), the poet Jordan Zandi expresses compliance with God's (i.e. logos, the active principle) order of things and implicit gratitude for sharing His 'inner fire': The dream is big, the dream is fancy:/ The dream is big and fancy.

Human heart becomes a metaphor for fire, a space integrating all Creation and containing as its core the world's active principle; Narcissus' metamorphosis into a flower expresses the unity of all Creation as changing forms by logos:

I wish my heart was as big as the world,/but bigger-(Zandi, op.cit.)

[...] there was no body. They came upon a flower, instead of his body, with white petals surrounding a yellow heart. (Ovid, op.cit., B III: 474-510, para 4)

\section{Time. Physical vs. psychological time}

Time should be analysed at different levels: above all, there is Time seen as an organizing principle, as a property of all things, represented as a god in ancient mythology; in monotheist religions Time becomes a dimension intrinsically associated to humans, God being not subjected to spatial-temporal limitations. Divine power is manifest in all phenomena, believes Heraclitus: 'God is day night, winter summer, war, peace, satiety hunger, and he alters just as 〈fire〉 when it is mixed with spices is named according to the aroma of each of them' (B67) (Graham, Daniel W., op. cit., part 4, para 14). Again 
Heraclitus seems to stress the unity of divine power, even if humans assigned different names and attributes to it. Time is seen first of all as physical time, perceived as a succession of days and nights, of seasons, and then, later, 'tamed' and levelled, in a way, by segmenting it into equal subdivisions: seconds, minutes, hours, days, weeks, months, years; nevertheless, each time unit is experienced differently according to its content (events) and to the emotional value of that content, thus becoming psychological time.

Time and space make up complex networks, turned into worlds, real or imaginary, the difference between real and imaginary, between what is observable, on the one hand, and what is imaginable and understandable through the power of the mind, on the other, becoming questionable, if not illusory. Imaginable worlds are, in their turn, also the result of intentions and desires; therefore reason, through imagination, volition and ability, contribute to the setting of the relationship mind-world.

Much of what can be said about time dimensions in the two poems was discussed in relation to space, since space is a concrete dimension which can be perceived and interpreted implicitly in relation to time coordinates: calendric days can be seen as spaces containing events evaluated emotionally and rationally, life and death can be imagined as two realms associated to what we know vs. what we can only hope/fear, but these two facets of existence are a function of time.

Pragmatically, we should distinguish between the coding time, i.e. present, and the reference time, associated to the moment, event/state considered as the anchor in relation to which all the other events are organised and, in the case of psychological time, interpreted.

For Zandi's poem the coding time is associated to a calendric time marker, absolute in nature, July 16, 2013, this date being mentioned at the beggining of the poem, which leads to interpreting the ideas of the poem within the situational context of contemporary time, the subjective connotation of this period for the poet being at best implicit. The whole succession of events is presented as instances of psychological time, internal time, in relation to oneself and in relation to other referents - one's roots, family, ancestors, symbolic everyday objects and beings.

Zandi begins a dialogue over time and space: at present with the readers, with the relevant people/beings in his past from the perspective of his present status, and with himself moving freely along the time axis and assuming the identity of the omniscient speaker or of the referents representing the personae of the possible (subjective) worlds described.

Zandi introduces the reference to daybreak, when Sun is sitting up, as a symbol of the beginning in life, with amazement and hope, in a quest for essence, for God. At the end of the poem, Sun is sitting up ever so slowly, time 
seems to change its rhythm, but this is because at the end of their earthly life humans change their perception of time.

The poem is also about the eternal beginning, beyond life and death, as long as Sun is sitting up: today is the reference moment for the poet because no obstacle blocks his quest for knowledge. In terms of human life periods, childhood should mean the beginning of life, whereas old age means the end of it at the level of matter. The poet might be closer to the end and his present disappointment at his fellows and his memories of the remote past imply that.

The Present Tense marking the reference time (the anchor event/state) is associated to Zandi's revolt against despiritualized matter - dead things and his determination to find the creating principle beyond flesh in all its concrete forms. Pragmatically, his questions addressed to his fellows, to us or to himself, have a directive function and are combined with primary performative utterances containing imperatives; both devices are meant to force people to react:

Tell me: What good is a life that wears away?

Oh! Look at this charming table:/already set;

Quick - to the window, Mother/come see - the coyote

Remember quinces, Jordan?

At the door, the red curtain is still flapping./Who will go in? (Zandi, op.cit.)

People's reaction means reflection, they should act upon time even if it seems inflexible matter, so as to get its echo sound, the mysterious whoosh: Sometimes time is iron. Swing it hard/ hear it whoosh.

Present Tense forms also express the poet's convictions extracted from his experiences and sufferings: I do remember quinces./Beautiful ones - I see you everywhere./ Hiding inside yourselves. Summer has an ambiguous significance: the summer when he tasted quinces, understood their essence and suffered could be the summer of his childhood holiday or the season of his becoming a mature person as a result of suffering.

The poet has flashbacks whose images retain the relevant elements for his present mind frame, those elements making up spiritualised spaces previously analysed in this paper. These flashbacks, generally considered to precede one's death, in Solarium acquire the reverse significance, as if Earth returns to mark a new beginning. Memories are just the pretext to deny the end, its permanence (The one who is going is going), to defeat matter by spirit, that 'inner fire':

No, I do not die here.

The year is wrong.[...]

And today no cloud cover.(Zandi, op.cit.) 
The poet reached that maturity of the spirit that allows him to detach himself from the past which holds him back: here means the condition of pure matter and he aims at reaching the empyrean (according to The MerriamWebster Dictionary 'the highest heaven or heavenly sphere in ancient and medieval cosmology usually consisting of fire or light'), i.e. spiritual accomplishment (I wish my heart was as big as the world,/but bigger -). $\mathrm{He}$ fights fate and re-creates its own destiny.

Death is seen by the poet as a state of mind, not of the body ( $I$ was a dead thing once), even if the latter may be frail: the rodent: cuddly; but a little dirty.I'll keep him as a pet, I'll pet him like/a luck-charm. The state of the body is irrelevant, it is secondary to the spirit, what matters at present is the reflection which gives the poet the vision of God spread in the roses, the vision of his reaching heaven and of reflecting on his vision; some might think it is unattainable and pure imagination; their implicit lack of confidence makes the poet even more convinced:

The dream is big, the dream is fancy:

The dream is big and fancy

Momentarily,

I'll be taken up

Like flame in a cloud like a cinder in fire

To outflap the empyrean - (Zandi, op.cit.)

Consumed by time, Man becomes essence, proving, as Heraclitus said, that a man's character is his guardian spirit (Graham, Daniel W., op. cit., part 2, para 11), therefore his fate. Relativity of time is expressed by Heraclitus in his objective and cryptical way: As the same thing in us are living and dead, waking and sleeping, young and old. For these things having changed around are those, and those in turn having changed around are these (B88) (idem, part 3.2, para 7).

Expressing general truths in the form of a story, Ovid does not explicitly manifest his own subjectivity, but views the succession of events with detachment and omniscience, since gods govern human lives. The connection between past and present in the light of Heraclitus' words lies in the fact that men's character is their fate and can be foreseen, as Tiresias did with Narcissus when he made his prophesy: Narcissus would live a long life if he does not discover himself.

The young man was the fruit of a violent immersion into the unknown and this trauma predisposes him towards the quest for essence for what is beyond form. Ancestry and pride are prerequisites that mark his destiny.

Born from a river god and a water nymph, 'Narcissus is water, i.e. he is flow, mystery, depth; the world of the depth is attractive to him to the same 
extent to which his mystery and depth are attractive to others, young men and women, who fall in love with him precisely for that reason. Nevertheless, his story is the story of living in danger of being physically drawn under water and of drowning, which, in ancient beliefs signified losing one's image assimilated to the soul. This is a spiritual loss which corresponds to the concrete loss of Narcissus' mother, abducted by his father and forced to submit to him under water. The Naiad Liriope lost control of her material existence because of her abductor's fire of desire. [...] Their son, Narcissus, was thus "genetically" bound to repeat their experience, on another scale. He is a human devoured by the fire of discovering himself in depth' (Pisoschi, 2017: 159).

Dual, he is past and present, boy and man. His adolescence makes the transition towards maturity. Physical perfection is completed by selfsufficiency, intense pride 'fills' that delicate form, hence the rejection of the others, at the same time learning to listen to Echo, Narcissus' inner voice. His psychological maturity comes as a result of suffering, of assuming his condition and going all the way in his quest for the self.

The defining actions and communicative behaviour of Narcissus and Echo, their stages in the process of change, are expressed by verbs in the Present Tense as general truths, whereas what represents the causal frame, i.e. projections from the past into the future, is rendered by Past Tense verbs. The use of time markers is irrelevant unless linked to the role of logos, the active principle.

\section{Logos}

Life means a journey in space and time and understanding the essence of the world, through words, but, accoding to Heraclitus, 'Although this Word is common, he warns, the many live as if they had a private understanding (B2). (Graham, Daniel W., op.cit., part 2, para 5) [...] Sound thinking is the greatest virtue and wisdom: to speak the truth and to act on the basis of an understanding of the nature of things (B112)' (Graham, Daniel W., op.cit., part 6, para 1).

Zandi's poem is in itself the illustration of putting the essence of the world into words, that is why it is impossible to separate matter from the active principle, the spirit that causes the change. Zandi becomes consciousness, spirit and enters various forms of matter manifested through logos.

In Ovid's poem, the word, logos, is Echo. But she suffers a metamorphosis herself, since in the beginning, she was indeed word, logos, i.e. order, knowledge, but the order concerning mainly matter, the body: 'her ,inner fire" is a reflection on a lower plane of Narcissus' fire. Her ascendence justifies that: Echo is a daughter of Gaea, Mother Earth (Zimmerman, 1966: 91), goddess of fertility, an association which doesn't actually contradict the variant of Echo's origin from water deities, because Gaea comprises 
everything connected to the material world. Secondly, the connection between Echo and the primordial element earth is expressed by her metamorphosis into stone, connoting [+permanence], [+stability], [+durability]. But stone is also inert matter, it signifies the lack of seeds, and symbolizes that Echo could not fulfil her instinctual drive. Hiding her body in the woods after being rejected by Narcissus is another proof of her belonging to the world of nature, dominated by the element earth' (Pisoschi, 2017: 163).

'Echo is Narcissus' counterpart, the passive element, she is reflection, but not the reflected; she is the hidden witness of Jupiter's passion for nymphs and encourages them, as she encourages her own passion for Narcissus, a purely sensuous passion' (ibidem). She breaks an essential principle stated by Heraclitus: that of sound thinking, of wisdom which implies speaking the truth. Initially, words were a game to Echo, she was not aware of their power. To protect gods, and, above all, love, she changes into spiritual excess (deceiving, hiding the truth) because of others' (gods') physical excess.

Therefore, her punishment is that she becomes reflection, a reflection of other people's words; she gradually loses her body, her materiality, since she reflects words, even sounds and gives them sense:

$O$ how often she wants to get close to him with seductive words, and call him with soft entreaties! Her nature denies it, and will not let her begin, but she is ready for what it will allow her to do, to wait for sounds, to which she can return words. (Ovid, M., B III: 359-401, para.4)

Love becomes a gift, once Echo can make sense of what she hears. Her punishment (Echo only repeats the last of what is spoken and returns the words she hears) means simplicity, but also deep meaning and ambiguity. What she loses in point of matter she gains as consciousness. She protected physical love and now she stirs love in Narcissus, but love for himself, for his inner nature that cannot express itself in words. Increasing reflection, sleepless thoughts, makes Echo hide her body and gradually become one with the nature, turning into a stone.

As for Narcissus, he also manifested excess, hybris, since he scorned love, which was considered an offence. He is blind to human love, and human blindness is one of Heraclitus' main themes. Narcissus' awareness increases when love becomes a burden, a punishment, and the only way out is detaching from his object of passion, separating the spirit from the body, being fully aware that it means death: I desire that what I love to be distant from me.

\section{Conclusion}

Understanding one's condition and attempting to surpass it means reaching harmony through the conflict of the opposites; it is continuity through change for eternity. All things that happen are good, even if human beings do 
not perceive them as such: 'To God all things are fair, good and just, but men suppose some things are unjust, some just (B102)'(Graham, Daniel W., op. cit., part 4, para 14).

Kahn's description of Heraclitus'style and goal (1979: 89) seems to us to perfectly match those of the two poets' texts analysed above. Descending from the cosmic realm deeply into the human world, without actually ever leaving the cosmos, both Ovid and Zandi, following Heraclitus' system and style, choose literary forms which to give the impression of objectivity, expressing independent truths:

He [Heraclitus] may be most concerned with the human relevance of philosophic theories, but he is an elitist like Plato, who thinks that only select readers are capable of benefitting from his teachings. And perhaps for this reason he, like Plato, does not teach his philosophical principles directly, but couches them in a literary form that distances the author from the reader. In any case he seems to regard himself not as the author of a philosophy so much as the spokesman for an independent truth.

Of the three fundamental forms of manifestation of matter, space, time and change, it is the last that moulds the human psyche through the creative principle, logos, the result being the configuration of unique worlds (spiritual spaces and psychological time spans). Between the known earthly dimension and the unknown (God's realm), man is in a perpetual quest for the essence through logos. With Zandi, spiritual evolution is desired to take place here, on Earth, by loving life beyond its material dimension, but through it. Thus, matter is defeated by spirit, man fights fate and re-creates his destiny, even if by just assuming it. With Ovid's Narcissus, essence is eternal and, once discovered, it defines man whenever and wherever.

\section{References:}

1. Kahn, C. H. (1979). The Art and Thought of Heraclitus. Cambridge University Press, Cambridge.

2. Kernbach, V. (1989). Dictionary of classical mythology, 2-nd edition. Scientific and Encyclopedic Publishing House, Bucarest.

3. Pisoschi, C. (2017). "Myths Turned into Wor(1)ds: from Ovid's Metamorphoses to Jordan Zandi's Solarium”. The Receive of GreekLatin Antiquity in European Cultures, Dana Dinu, Mihaela Popescu, Mădălina Strechie (eds.). Proceedindgs of the International Colloquium The Receive of Greek-Latin Antiquity in European Cultures, 9-th edition, 26-27 May 2017. Universitaria Publishing House, Craiova, pp. 153-166.

4. Zimmerman, J. E. (1966). Dictionary of Classical Mythology. Bantam Books, NY, Toronto \& London. 


\section{Electronic references:}

5. Empyrean. (n.d.). In Merriam-Webster online Dictionary. Retrieved from www.merriam-webster.com/dictionary/empyrean

6. Graham, Daniel W. (2015). "Heraclitus", The Stanford Encyclopedia of Philosophy (Fall 2015 Edition), Edward N. Zalta (ed.), URL = https://plato.stanford.edu/archives/fall2015/entries/heraclitus/> (revised on June 23, 2015).

7. Marinescu, D. (2003) 'Narcissus' Metamorphoses'. Metamorphoses: Image - Text. Iconology Studies, Dan Grigorescu, Alexandra Vrânceanu (eds.). University of Bucharest. Retrived from https://www.ebooksunibuc.ro/filologie/metam/6.htm/11/9/2017

8. Solarium. (n.d.). In Merriam-Webster online Dictionary. Retrieved from https://www.merriam-webster.com/dictionary/solarium

\section{Source texts:}

9. Ovid. (n.d.) Metamorphoses (the online English version of Anthony S. Kline. Retrieved from http://ovid.lib.virginia.edu/trans/Metamorph3.htm\#476975712/06/27/ 2017

10. Zandi, J. (n.d.). Solarium. Retrieved from https://newrepublic.com/article/113564/solarium-poem-jordanzandi/06/27/2017

11. https://www.jordanzandi.com/poems 